ORCID 0000-0002-3540-481X Institute of Applied Social Sciences University of Warsaw 1

\title{
How to capture these benefits? Systematic review of Polish literature on impact measurement in the social economy ${ }^{2}$
}

\begin{abstract}
The article presents results of a systematic literature review concerning measurement of the social impact of social economy entities and social enterprises. The query mainly covered leading Polish databases of scientific journals and publications as well as electronic university repositories. 463 texts were identified, 34 were included in the review. The article presents definition issues regarding social impact and the reasons indicating the necessity of measuring it. Social impact measurement methods most frequently proposed in the literature are also shortly presented: Prove and Improve, Social Audit (SA), Social Return on Investment (SROI), Local Multiplier (LM3), Balanced Scorecard (BSC), ESometr.
\end{abstract}

Key words: social economy, evaluation, social impact

1 Correspondence: Instytut Stosowanych Nauk Społecznych UW, ul. Nowy Świat 69, 00-001 Warsaw, Poland, author's email address: szymon.wojcik@uw.edu.pl.

2 The article is based on the report: Szymon Wójcik, "Systematic review of Polish literature in the scope of social impact measurement methods" (Przeglad literatury krajowej w zakresie sposobów mierzenia oddziatywania społecznego) prepared under the project "Social economy participatory management system" coordinated by the Ministry of Family, Labour and Social Policy, co-financed from the EU funds under the OP KED 2014-2020. 
Introduction

The aim of this article is to analyse Polish scientific publications on measuring social impact of social economy entities and social enterprises. The presence of this issue in Polish scientific literature is relatively low. First publications in this field appeared in Poland slightly over a decade ago, however this topic still remains rare in the discourse on social economy and, more broadly, on social policy in Poland.

Social impact has numerous definitions, it is however most commonly understood as a certain additional benefit for society (in some approaches also for the natural environment) stemming from the conducted activity. Therefore, it is added value which goes beyond direct benefits for the beneficiaries of a given activity. The term was also used in contrast to the purely economic value (Harlock, 2013). As such, it is particularly important in the context of social economy, where it may serve to conceptualise and operationalise social value coming from that field which is more difficult to capture than the monetary value produced.

Social impact measurement falls within the general scope of evaluation research understood as the process of methodological, reliable assessment of the conduct and outcomes of a given activity (Szarfenberg, 2010). However, it focuses on a specific aspect of the social impact assessment. This distinction is commonly linked with the impact value chain concept deriving from the evaluation research theory (Dufour, 2019; Maas \& Liket, 2011; SIIT, 2014). It is a logical cycle starting from the inputs allocated to a given project, through conducting the activities, outputs being their direct effects, to broadly understood outcomes. The last and the furthest reaching influence level is the social impact which may also be understood as a "net" result after considering other variables influencing the final social situation. Therefore, the impact measurement may be understood as a subtype of evaluation distinguished for its purpose and material scope (Szatur-Jaworska, 2010). Some scholars distinguish this field as originating from the same core but currently distinct from evaluation research in terms of its concept. The cause of such a distinction lies mainly in greater prevalence of social impact measurement in private sector (non-governmental and commercial entities) and of programme evaluation in public sector (Dufour, 2019).

\section{Method}

The report was created with the systematic literature review method. It grants the possibility to synthesize numerous scientific research and publications in order to find and organise possible answers to a given research question. The systematic review was based on the methodological assumptions in Polish and foreign literature, especially in international guidelines, such as PRISMA (Preferred Reporting Items for Systematic Reviews and Meta-Analyses) (Moher, 2009; Orłowska et al., 2017). According to these guidelines, the review procedure included several steps. The process started with defining 
the research objectives. Next step consisted in searching and obtaining Polish literature, deriving important data and conducting quality assessment of the collected materials. After developing the corpus of materials, the results were analysed and synthesised, and included in this article.

This systematic review's research objective is the analysis of ways of conceptualisation and operationalisation of the social impact of social economy entities, identifying theoretical and practical problems, issues and challenges related to the social impact measurement, as well as cataloguing the most important methods used for their measurement in Polish research and social practice.

We may thus indicate the following research questions, complementary to each other:

1. How is social impact and its measurement defined in Polish literature?

2. Which theoretical and practical problems are related to the social impact measurement in the Polish context?

3. How (with the use of which tools) may social impact be measured by social economy entities and social enterprises, as well as for public interventions and policies?

For the purpose of systematic review, it was necessary to set inclusion and exclusion criteria constituting the boundary conditions for including publications in the review. The systematic review involves publications published in Polish. Considering the adequacy of knowledge and research results in relation to current situation, the systematic review includes publications published no later than 20 years ago (since 1999). It comprises scientific articles and monographs, i.e. reviewed scientific literature. Systematic literature reviews may also include non-scientific specialised publications called "grey literature". This category is especially important for the analysed problem. A significant part of papers on social impact measurement is written not in a strictly scientific environment, but while working on concepts for various social and public projects. Therefore, the systematic review could include also publications by non-governmental organisations and other entities.

The basic substantive criteria that publications had to fulfil in order to be included in the systematic review are as follows:

a) Containing definition or typology of social impact of social economy entities, social enterprises and public policies, and/or:

b) Containing proposition of indicators for measuring social impact of social economy entities, social enterprises and public policies, and/or:

c) Containing results of basic or applied research (including evaluation research) concerning measuring social impact of social economy entities, social enterprises and public policies.

Three searching methods were used for the development of the systematic review:

1. Using electronic scientific literature databases enabling access to full length articles and books. 
2. Scanning bibliographies of publications already obtained for further publications fulfilling the eligibility criteria.

3. Searching in additional sources - mainly lists of publications on websites of social economy organisations, such as centres for social economy support.

The search included four Polish electronic scientific journals and publications databases, one collective repository $(\mathrm{CEON})$ and 15 university repositories gathering scientific articles of their employees, but also doctoral and habilitation dissertations.

Table 1 presents keywords that were used for searching databases in order to identify publications to be included in this systematic review. They are in the form of string of words linked by logical operators (so called search strings). The first element concerns various terms for social impact (social benefits), the second one concerns the type of entities under research, and the third one - the measurement aspect.

Table 1. Keywords (search strings) for searching the literature

\begin{tabular}{|c|c|c|c|c|}
\hline $\begin{array}{l}\text { Social impact } \\
\text { [Oddziaływanie społeczne] } \\
\text { OR } \\
\text { Social influence } \\
\text { [Wpływ społeczny] } \\
\text { OR } \\
\text { Social added value } \\
\text { [Społeczna wartość dodana] }\end{array}$ & AND & $\begin{array}{l}\text { Social economy } \\
\text { [Ekonomia społeczna] } \\
\text { OR } \\
\text { Social policy } \\
\text { [Polityka społeczna] } \\
\text { OR } \\
\text { Public policies } \\
\text { [Polityki publiczne] }\end{array}$ & AND & $\begin{array}{l}\text { Measurement } \\
\text { [Pomiar] } \\
\text { OR } \\
\text { Indicator } \\
\text { [Wskaźnik] } \\
\text { OR } \\
\text { Research } \\
\text { [Badanie] }\end{array}$ \\
\hline
\end{tabular}

Source: Own work.

The whole process may be summarised with the use of so-called float diagram (Figure 1). It presents subsequent steps of conducting systematic review. The source of publications consisted of two main data streams: searching bibliographical and full-length text databases and bibliographies in already identified articles. This resulted in the initial set of publications which was subject to a two-stage selection process. The first stage consisted in analysis of only titles and abstracts. That enabled a relatively fast elimination of a significant number of publications not fulfilling the basic criteria or concerning different topics in their substance. In the second stage, full texts of publications were analysed. Also in this case the publications not fulfilling eligibility criteria were eliminated. Such an elimination resulted in a final corpus of publications which were further analysed in their substance.

During the search process, no publications published earlier than in 2006 were identified. More articles emerged in 2008 and in subsequent years. In that period, 4 to 6 texts fulfilling eligibility criteria were being published every year. The detailed search covering databases and bibliographies granted possibility to identify, with high probability, all the scientific texts that were published in Poland and concerned the issue of social impact measurement as their main topic. 
Figure 1. Float diagram for the literature systematic review

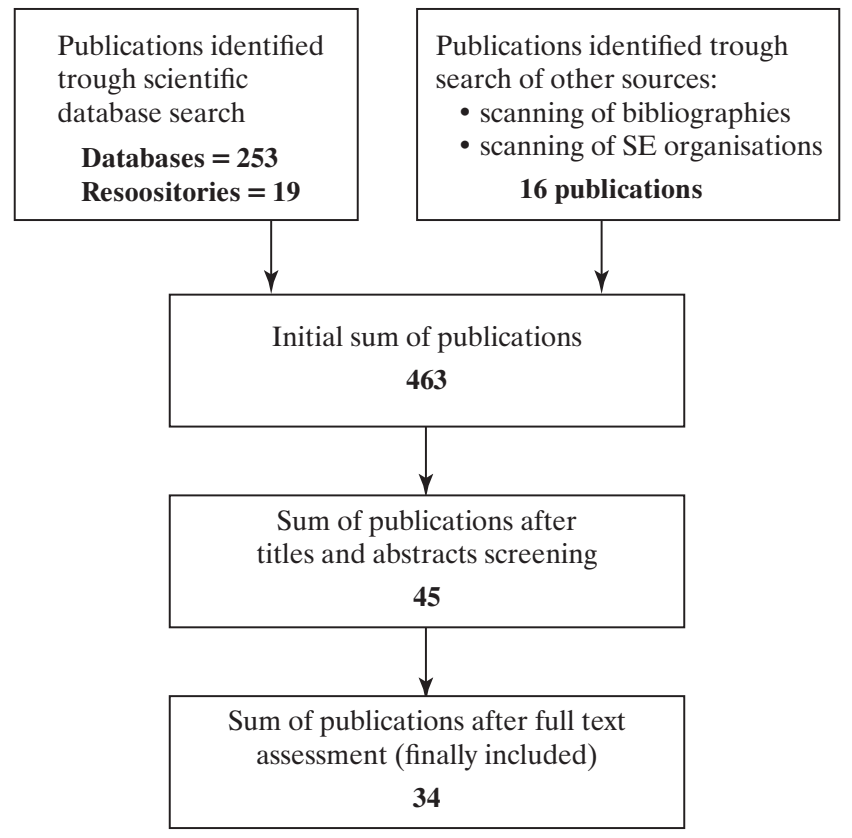

Source: Own work.

\section{Social impact measurement - theoretical and practical aspects}

The issue of measuring social impact of enterprises from the scope of social economy and of other social enterprises is rarely covered in the Polish scientific literature. It is related to the fact that both general evaluation culture and the practice of conducting regular effectiveness assessment of this kind of enterprises, is less developed in Poland than in western countries (Krawczyk \& Kwiecińska, 2008). Nevertheless, there is a valuable and constantly growing corpus of Polish scientific literature on both, theoretical and practical aspects of social impact measurement, which has been analysed in this systematic review.

The first article, in chronological order, that was entirely devoted to methods and techniques of measuring social impact of social enterprises (identified under the systematic review) was published in the "Trzeci sektor" quarterly in 2006 (Bohdziewicz-Lulewicz, 2006). The publication of this article followed on international project implemented under the EQUAL Community Initiative in partnership with British organisations which brought in their know-how in the field of evaluation. Numerous later publications also aimed at the transfer of knowledge derived from the western experience. Authors confront them with the national context of social economy functioning. In 2008, first guide publications appeared - they served as an instruction for social economy entities on how to operationalise impact measurement (Juraszek-Kopacz \& Tyrowicz, 2008; Krawczyk \& Kwiecińska, 2008). 
As the majority of definitions applied in the analysed texts are based on foreign literature, it is worth discussing the difficulty related to translation of the terms used in this literature. First of all, it concerns the word "impact". The term is widely used in social sciences and its Polish dictionary equivalent is in this context "wpływ" or "oddziaływanie". However, these equivalents lose the aspect of force of influence which is characteristic to the English original term ${ }^{3}$. In Polish literature, the term "social impact" is translated as both, "wpływ społeczny" (Bohdziewicz-Lulewicz, 2006; Jastrzębska, 2017; Wróblewska, 2017) and "oddziaływanie społeczne" (Juraszek-Kopacz \& Tyrowicz, 2008; Kafel, 2012). The second term seems to be more reasonable, as the term "wpływ społeczny" is already well established in the Polish scientific language in different meaning - in the field of social psychology and marketing theory it describes the influence other people have on individuals' behaviour, which is known in English language as social influence or social compliance.

The notion of social impact (influence) is often completely missing its definition in the analysed publications, or is defined in very general terms, e.g. as "consequences of a given enterprise going beyond the immediate results" (Guz, 2008, p. 51). A more elaborate definition describes social impact as "a long-term, constant change for beneficiaries, local community or the whole society, e.g. an improvement in the quality of beneficiaries' life, improved safety in the district or savings in public expenditure" (Juraszek-Kopacz \& Tyrowicz, 2008, p. 26). Several approaches describe both positive and negative impact, since it should not be assumed that the impact of the social enterprise's activity cannot be negative (even when it is non-intentional) (Jastrzębska, 2017). It should be noticed that the definitions do not cover such aspects as correcting the impact for counterfactual situation (the probable course of events in the case in which the activity did not take place), which is common in foreign literature.

The systematic review results indicate that the Polish literature uses more widely an expression of "Social Added Value" (SAV) which is more common than social influence or social impact. It may be understood as "social impact's measurable aspect" (Juraszek-Kopacz \& Tyrowicz, 2008). In other approaches it is simply used interchangeably with the term of social impact (Krawczyk \& Kwiecińska, 2008).

Social added value is defined on the basis of international sources as "an additional benefit constituting a positive result (for people, environment, local community) produced by an organisation in the course of making products or providing services that the recipient pays for" (Krawczyk \& Kwiecińska, 2008, p. 94). It is worth noting that the above mentioned definition includes both, individual benefits (building of human capital) being the main objective of working integration social enterprises (WISE), as well as community benefits, increasing social cohesion (building of social capital), which, in its turn, is a priority for enterprises aiming at local development (Łącka, 2015; Rymsza, 2011).

3 The English term "impact" is much more powerful than the term "influence". "Impact" is also synonymous with the terms "impetus", "crash" etc. 
Another significant publication defines social added value in a different manner, as "the level in which social economy entities are socially useful. Social usefulness is understood as (...) the level in which these entities meet the objectives they are faced with" (Głowacki \& Jelonek, 2013, p. 15). The second definition may arouse controversies, as it requires specifying what kind of objectives it refers to. If it concerned the objectives set by the organisation itself, this definition would be overly restricted. After all, the concept of measuring social impact and social added value includes also situations involving social benefits that were planned neither by the parties carrying out the activity, nor by those programming it (the so-called external positive results).

Social added value is a concept that may be understood in two manners: in a narrow sense as a trend of defining social results of organisation's activity from a financial perspective, and in a broader sense as an attempt to capture the entire positive impact on society (considering quantifiable and non-quantifiable benefits) (Głowacki, 2010, 2015). There was even an idea in the literature to use the term "enterprises of social added value" interchangeably with the term social economy entities (Herbst, 2006). This concept was applied e.g. to diagnose the extent to which a given type of entities may be ascribed to the social economy sector (whether they bring the social added value) (Płonka, 2013). At the same time opinions may be found stating that the social added value's definition is highly ambiguous (Balsewicz, 2015).

Yet other authors do not use the term social impact nor the term social added value, but they write about broadly understood efficiency of social economy entities, which consists of components of economic viability and social benefits (social viability) (Płonka, 2008; Rymsza, 2011). It is emphasised that due to the hybrid nature of social economy entities, measuring their efficiency constitutes a complex and multidimensional process. It has to consider efficacy and effectiveness aspects, financial and non-financial dimensions, as well as take into account the changes in time (dynamic aspect) and the environment (beneficiaries, stakeholders) (Goleński, 2017). The notion of efficiency is also linked in the literature with the social added value concept - it is proposed, for example, that the added value creation coefficient should be used as a basic meter for assessing the efficiency of social enterprise (Duraj, 2011).

Wronka (2014) proposes, in her turn, using the term "success" borrowed from the management and entrepreneurship sciences. This is a broader concept and besides fulfilling social objectives it proposes considering organisation's financial stability, ability of gaining new resources and of development, as well as its social legitimacy.

To sum up this part, it should be noticed, that as for agreeing on terms and definitions in the scope of social impact measurement, there is still room for further work and development. There is no terminological coherence and the definitions in place tend to be imprecise or limited. Multitude of different approaches (as well as translations and adaptations of English terms) may make it difficult for scientists and experts to exchange ideas, and in longer perspective, to propose practical solutions. 


\section{Need for social impact measurement in the Polish context}

The majority of analysed articles and publications emphasise poor dissemination of social impact measurement methods in Poland in spite of the growing popularity of the social economy itself (Bohdziewicz-Lulewicz et al., 2012). The first pioneering research on knowledge and needs in this field (of pilot nature) conducted in 2006 with participation of persons responsible for shaping public policies in the social economy area and persons managing social enterprises has already shown, that social impact measurement methods are neither known, nor used in our country. At the same time respondents indicated that such methods would be desirable, however under two conditions (Bohdziewicz-Lulewicz, 2006):

a) indicators used in such evaluation should be selected in a way to match the objectives and activities of particular organisations and their local conditionalities;

b) non-economic indicators should be the primary focus points.

As for the first condition, on the one hand it may be treated as the need for having research tools adjusted to specific needs, on the other hand, it may reflect concerns in using standardised tools that would enable quick comparison of indicators among different entities (which is the essence of many measuring methods). The second condition may, in its turn, be interpreted in the context of incomplete understanding of assumptions of the blended value theory which is assumed to combine economic and non-economic values measurement (which also reflects the hybrid nature of social economy entities).

Głowacki and Jelonek (2013) have identified external (in relation to social economy entities) and internal grounds for the need of conducting social impact measurement. The external grounds include:

- necessity of accountability towards public funding institutions (governmental, regional, union);

- competition among social economy entities for access to public and private funds (and resulting necessity of making comparison of efficiency and effectiveness);

- quality control concerning services provided by social economy entities expected by funding institutions;

- necessity of developing standards and procedures systematising the functioning of social economy sector.

Internal grounds include, among others:

- necessity of confirming the usefulness and effectiveness of undertaken activities by social economy entities themselves (self-evaluation);

- communication with environment, stakeholders, creating its image.

As a result, the following groups interested in impact measurement tools were indicated: social economy entities themselves, supporting and funding institutions as well as institutions awarding prizes, certificates or labelling systems for social economy entities.

The multitude of internal and external grounds for social impact measurement in social economy is in the majority of analysed publications combined with the statement that this area is not well developed in our country, and its popularisation constitutes a significant challenge. 
Many authors are convinced that Polish non-governmental organisations and social enterprises not only fail to measure social impact methodically, but, focusing on conducting current activities, they neglect reflection on the broader context of their activities at all: "How should we know that organisations really contribute to addressing social problems? What have they achieved? Are they effective? (...) These key questions concerning the reliability of organisations in Poland often remain unanswered" (Juraszek-Kopacz \& Tyrowicz, 2008, p. 15).

Although conditions for using union funds and other grants often include the requirement of conducting evaluation (which to a certain extent corresponds with impact measurement as for its objectives), such evaluation is often carried out in a manner that is methodologically incorrect or unreliable (Bohdziewicz-Lulewicz, 2006; Worek, 2008). It focuses on short-term results of activities, and not on their long-term impact (Juraszek-Kopacz \& Tyrowicz, 2008). The positive aspect of popularising evaluation related to EU-funded projects consists in spreading the understanding of such notions as objectives, indicators, products, etc., also at the local level, which is useful while conducting possible impact measurement (Krawczyk \& Kwiecińska, 2008).

However, the key question is if the social entrepreneurs themselves are aware of the need of conducting evaluation and if they know what kind of benefits they would be able to gain from it. The role of external experts and evaluators may be crucial in this case, as they should pay attention not only to methodological robustness of the conducted evaluation, but also to its understanding and usefulness to all recipients. Too often evaluation research is developed exclusively for funding or controlling institutions, and the aspect of its use by conducting entities themselves is simply neglected. This underpins the overall trust in the whole scientific evaluation among social entrepreneurs (Worek, 2008).

The overall low level of awareness is combined with other additional problems related to the specificity of Polish social economy sector. These are difficulties related to the level of development, access to resources, as well as legal and organisational forms of functioning (Bohdziewicz-Lulewicz, 2006).

A crucial question is related to the relatively low level of "marketisation" of Polish social economy entities. Although taking economic risk is a part of their nature, significant percentage of entities in the Polish context, even among such social enterprises as social cooperatives, rely to a larger extent on resources from public support than on revenue from economic activity. This means that the role of "market verification" is less significant, hence the role of social impact assessment considering non-financial aspects increases (Worek, 2008).

Another practical issue consists in functioning of many Polish social economy entities in "conglomerates" (e.g. association accompanied by social integration centre (CIS), vocational activity establishment (ZAZ) and social cooperative). Such a situation makes it difficult to separate both, costs and benefits (especially social ones) specifically linked to an entity subject to research. In many cases impediments appear already at the stage of access to basic data, when individual entity does not keep separate accounts (Bohdziewicz-Lulewicz et al., 2012). 
The overall problem indicated by many authors consists in low level of physical and human capital of Polish social economy entities, which results in the lack of resources for conducting comprehensive evaluation (Bohdziewicz-Lulewicz, 2006; Juraszek-Kopacz \& Tyrowicz, 2008; Krawczyk \& Kwiecińska, 2008). However, it is worth noticing that the same question is raised by foreign authors, and that the methods do not need to be highly cost-intensive and time-consuming, and, most of all, numerous methods are "scalable" depending on the size of the enterprise. To sum up, it is difficult to decisively state which challenge is more important for popularising impact measurement methods: lack of awareness and willingness from the part of social economy entities, or lack of resources and possibilities.

\section{Social impact measurement methods applied in Poland}

The Polish literature describes also a number of specific social impact measurement methods. Two approaches may be distinguished among them: authors presenting and testing the most popular foreign research techniques and methods, and those working on their original proposals. The most frequently quoted methods and techniques have been presented below: Prove and Improve, Social Audit, Social Return on Investment (SROI), Local Multiplier 3 (LM3), Balanced Scorecard (BSC). As for the Polish proposals, the most extended tool, namely ESometr, has been included (Głowacki, 2013).

\section{Prove and Improve}

The Prove and Improve method is a proposal consisting in adaptation of the British method developed by New Economics Foundations (Juraszek-Kopacz \& Tyrowicz, 2008; Kafel, 2012). It is not an independent tool, but rather a framework method enabling using various measuring tools depending on the needs and possibilities. The proposal is of major importance, as it has been presented to Polish recipients in a relatively precise manner, in the form of already mentioned practical guide entitled "To measure the unmeasurable. On social impact measuring" (Zmierzyć niemierzalne, czyli o pomiarze oddziatywania spotecznego) (Juraszek-Kopacz \& Tyrowicz, 2008).

According to authors, the main philosophy underpinning the Prove and Improve method consists in transition "from measuring what is evidently measurable, to measuring what is crucial” (Juraszek-Kopacz \& Tyrowicz, 2008, p. 10). It serves as a starting point for reflection on such notions as social impact and social added value. The authors make an assumption that conducting this kind of evaluation is what enables the reflection on the real changes brought into people's life by the activity of a non-governmental organisation or a social enterprise. Therefore, it enables them to carry out their mission in a more informed and improved manner in further perspective. 


\section{Social Audit}

Another proposal of similar nature is the Social Audit (SA) method. As in the case of Prove and Improve method, this is not a specific research tool, but rather a name of a broader approach to social impact measurement. The method was developed for corporations concerned about the corporate social responsibility (CSR). Over time, it has also been adapted by social economy entities (Bohdziewicz-Lulewicz et al., 2012). Social Audit is discussed relatively often in the analysed selection of literature (inter alia, Bohdziewicz-Lulewicz et al., 2012; Głowacki, 2010; Głowacki et al., 2012; Krawczyk \& Kwiecińska, 2008).

Social Audit was created as a method analogous to the traditional financial audit and it was to verify the effectiveness and efficiency of fulfilling non-financial objectives. It produces best results when used jointly with the so-called Social Audit and Accounting (SAA). The SAA consists of monitoring the fulfilment of social objectives on an ongoing basis, with the use of appropriate indicators. Their fulfilment is recorded in the "accounts" in an analogous way as in the case of accounting financial operations. The audit itself should be conducted on a regular basis, preferably once a year.

As for its merits, Social Audit's basic assumptions do not differ significantly from those indicated for the Prove and Improve method, or simply from an in-depth evaluation. The difference lies in the adopted perspective. Social Audit aims mainly at verifying if an organisation or a project creates impact in line with the assumed objectives and according to the plan. It is to detect possible incorrectness, imprecision or poor management (Głowacki et al., 2012).

\section{Social Return on Investment}

Social Return on Investment (SROI) is one of the most popular and most widely discussed social impact measurement methods. It is quoted in the majority of Polish review texts (Głowacki, 2010; Głowacki \& Jelonek, 2013; Juraszek-Kopacz \& Tyrowicz, 2008; Krawczyk \& Kwiecińska, 2008; Łącka, 2015; Rościszewska, 2015). The analysed literature also includes texts specifically devoted to the application of the SROI method (CKS, 2010; Moroń \& Klimowicz, 2016; Oramus, 2011).

In brief, the SROI method assumes estimation of the value of the sum of investments in a given organisation's activity and referring it to the sum of benefits - financial, social and environmental (ecological) brought by that activity. In order to develop a synthetic measure, the method assumes translating all identified benefits into financial amounts (so called monetisation). For example, providing work to the long-term unemployed may be valued by estimating amount of money "saved" by the state amounts of unpaid unemployment benefits or benefits from social assistance. The final SROI indicator figure indicates the overall socio-economic rate of return on investment (e.g. SROI 3:1 represents socio-economic benefits of PLN 3 from every PLN 1 that has been invested). 
The analysed selection of publications includes a valuable article by Marek Oramus (2011), which is an external research of Ale Heca! foundation from Cracow conducted using the SROI method. This small organisation was organising developmental activities for children and youth, as well as other forms of support for parents whose annual income did not exceed PLN 30 thousand. The analysis carried out resulted in SROI indicator of 7.2 (return on investment of over $700 \%$ ). The entire annual input has hence been returned after only 50 days of foundation functioning. This example proves that it is possible to use SROI method in Polish context, even for small entities. The results of such analyses may be positive, and they may present the social enterprises' value in line with the method's assumptions. It is however interesting, that this is the only example of fully conducted analysis of a specific entity that has been found in the course of systematic literature review.

The method is sometimes criticised for being overly complicated, costly and unreliable (Bohdziewicz-Lulewicz et al., 2012; Głowacki \& Jelonek, 2013; Lącka, 2015). The authors of one of the articles conclude: "it does not appear probable that the social economy entities in Poland, who still have poor financial and organisational potential, would be interested in this kind of solution" (Bohdziewicz-Lulewicz et el., 2012, p. 19). Taking into account this method's global popularity, it should be considered to what extent such lack of interest results from the weaknesses of the method itself, and to what extent it is the result of complete unfamiliarity with this method or its insufficient popularity as well as the lack of accessible tools.

\section{Local Multiplier (LM3)}

Similarly to SROI, Local Multiplier LM3 also has its origins in economic sciences, but its application is more limited. It does not refer directly to the term and concept of social impact, as it only indicates the amount of organisation's income that is reinvested in local economy. This is especially important for social economy entities aiming at local development. The number 3 in the method's acronym refers to three circulations of money. The first one is the original income (e.g. the overall amount of annual organisation's income), the second one is disbursement of these money by organisation (how much was invested internally, and how much externally), and the third one is the way of spending the money by entities which received them in the previous circulation (e.g. employees spending their remuneration, suppliers spending their income, etc.). The indicator takes the value from 1 to 3 , where 1 signifies spending the whole original income outside the local economy, and 3 represents a situation in which not only organisation spent all her money locally, but also those who received them (this is a clearly hypothetical situation in practice, part of money leaks out with every circulation).

Similarly as in the case of SROI, in the course on review only one article has been found in which the LM3 analysis was conducted on the Polish grounds. In 2010, Przemysław Świeczkowski (2011) made such calculations for three social cooperatives in Cracow. The LM3 indicator value for these entities amounted to 1,16; 1,69 and 1,76 respectively in the two last cases it may be stated that the values were relatively high (in practice 
the LM3 indicator does not exceed 2,2). For the cooperative with the highest score, this meant that the investment in cooperative amounting to PLN 48,000 boosted the Cracow economy by additional PLN 36,595. Although the analysis has limited nature, this example proves that it is possible to apply this method in Poland, and its potential is almost non-recognised so far.

\section{Balanced Scorecard}

The Balanced Scorecard (BSC) is of different nature, as it originates form the management sciences and it is used in big enterprises as an instrument supporting strategic management. There is a number of this method's varieties adjusted to social enterprises.

Unlike the SROI method which considers all the results in monetary terms, BSC originally served to extend the assessment of enterprise functioning beyond the purely financial indicators. The original method developed by R. Kaplan and D. Norton covered the assessment of four perspectives: financial, customers, internal processes and growth. In each of these areas the organisation sets its objectives and indicators marking their fulfilment by herself. In the social economy context, the customers perspective may be extended by stakeholders and the impact on beneficiaries, local community, etc. may be measured (Somers, 2005).

This method is even less known in Poland than the above mentioned methods. Review articles typically quote it only by its name, and it is more closely described in two of them (Głowacki et al., 2012; Lącka, 2015). Only two articles fully devoted to this method in the social economy context were identified in the course of the review (Bohdziewicz-Lulewicz, 2008; Chodyński et al., 2007). No publications of the case study nature were found that would describe the application of the BSC method in a specific social enterprise. Considering its flexibility and its quality of being well rooted in theory, it is regrettable that the popularity of this method in Poland is so poor. In contrary to SROI and LM3, it does not require any knowledge from the scope of accountability. However, experts' recommendations are ambiguous. While one author concludes that "it is an extended and time- and work-consuming method" (Lacka, 2015, p. 249) and doubts the possibility of its implementation in Poland, another author writes that "BSC seems to be a good method for measuring social impact of organisation, fulfilling a number of additional functions necessary for professionalisation of social enterprises" (Bohdziewicz-Lulewicz, 2008 , p. 67). Other authors add that the method is "complementary for the majority of methods for assessing organisation's quality indicators, its application is therefore universal" (Głowacki et al., 2012, p. 344).

\section{ESometr}

Although the literature most frequently refers to one or several of the above mentioned methods and techniques developed in the west, according to some opinions foreign solutions are not adequate to Polish situation. These arguments refer to already 
discussed problems of social economy in Poland - variety of entities, limited resources, lack of organisational and financial possibilities to conduct extended evaluation research (Głowacki \& Jelonek, 2013).

The assumptions about the necessity of creating a national tool adjusted to Polish situation constituted the basis for developing the only, as so far, widely known Polish tool for measuring social impact of social economy entities named ESometr. This tool was created in 2013 and it has been popularised mostly by researchers from the Małopolska School of Public Administration of the Cracow University of Economics (MASP UEK) who participated in works on its development (Bohdziewicz-Lulewicz et al., 2012; Głowacki, 2013; Głowacki \& Jelonek, 2013). Currently, it is also referred to by other researchers (Chomiuk \& Gabryelewicz, 2017).

ESometr is based on a fixed set of indicators which were translated into questionnaire available online and free of charge ${ }^{4}$. As such, the tool is to constitute a widely available proposal also for small organisations. Using the tool does not bear any initial costs, it is not necessary to hire an external expert, and the results in the form of tables and charts are automatically generated. Despite these facilitations, it has been concluded already at the pilot research stage that social economy entities are poorly motivated to participate in the research (Bohdziewicz-Lulewicz et al., 2012). Unfortunately, statistics available on the ESometr website also indicate very low popularity among users.

The strength of this tool lies undoubtedly in its standardised nature and the resulting possibility of using the data to compare entities (the authors themselves encourage bodies awarding grants to use it while assessing the entities that apply for funds). At the same time, although entities may choose their size for the assessment, many aspects concerning their potential social impact may be neglected. This may be especially true for social economy entities which do not fit in the typical WISE model.

\section{Conclusion}

The systematic review of Polish literature on social impact measurement indicated that this practice is still poorly recognised and rarely applied. At the same time, numerous authors convincingly present possible benefits of its application. Some of them engage directly in their popularisation and implementation in Poland.

The analysed corpus of literature is relatively small when compared to an enormous amount of foreign literature concerning the question discussed. There is certainly room for further scientific work and for the transfer of knowledge to the social economy sector. Already the area of terms and definitions requires more thorough elaboration and systematisation of the expressions used (the notions of social impact, social influence, social added value, efficiency). There is certainly also room for more empirical research aimed at diagnosing the needs of social entrepreneurs and supporting institutions from the social economy environment.

${ }^{4}$ ESometr is available on the website: http://swd.msap.uek.krakow.pl. 
The practical field requires even more work. The review presented attempts to demonstrate the most important measuring tools and methods in Poland. Some of them, however, were not fully adapted, and the detailed instructions enabling their practical use in organisation or institution were not developed. The insufficient number of case studies presenting application of specific methods on a particular organisation is a highly significant conclusion from the review. A few existing publications of this sort (Oramus, 2011; Smoter, 2012; Świeczkowski, 2011) seem to suggest that the area has significant potential and the practical implementation may be more successful than it is suggested by general, pessimistic forecasts.

The compilation of all, or at least the majority of Polish publications in this field, that were produced over the last decade, may, on the one hand, constitute the basis for further scientific work on this matter, and on the other hand, it may serve as a sort of the mapping of needs and it may indicate directions that require development in the future in order to popularise social impact measurement.

\section{References}

Balsewicz, A. (2015). Wartość dodana generowana przez podmioty ekonomii społecznej korzyści ekonomiczne i społeczne. Wspótczesne Problemy Ekonomiczne, 11, 107-114. Bohdziewicz-Lulewicz, M. (2006). Metody i techniki mierzenia społecznego wpływu przedsiębiorstw społecznych, czyli jak uchwycić wartość dodaną podmiotów ekonomii społecznej. Trzeci Sektor, 7.

Bohdziewicz-Lulewicz, M. (2008). Balanced Scorecard jako narzędzie pomiaru oddziaływania społecznego w przedsiębiorstwach społecznych tworzonych przez organizacje pozarządowe w Polsce. Ekonomia Społeczna, 2, 61-68.

Bohdziewicz-Lulewicz, M., Gil, B., Głowacki, J., Jelonek, M., \& Rosiek, K. (2012). Pomiar społecznej wartości dodanej generowanej przez podmioty ekonomii społecznej główne dylematy i wyzwania. Ekonomia Społeczna, 2, 16-32.

Chodyński, A., Jabłoński, M., \& Jabłoński, A. (2007). Rola zaufania w budowie jakości relacji przedsiębiorstw i organizacji non profit z wykorzystaniem Strategicznej Karty Wyników. Problemy Jakości, 5, 39-42.

Chomiuk, A., \& Gabryelewicz, K. (2017). Efektywność przedsiębiorstw społecznych w realizacji celów społecznych i biznesowych. Ekonomia Spoteczna, 1, 72-83.

CKS. (2010). Zastosowanie analizy i wskaźnika SROI w Europie i Kanadzie. Downloaded from Urząd M. St. Warszawy — Centrum Komunikacji Społecznej website http://strategia.um.warszawa.pl/content/zastosowanie-analizy-i-wska-nika-sroi-w-europie-i-kanad zie (access: 9.01.2019).

Dufour, B. (2019). Full Length Article: Social impact measurement: What can impact investment practices and the policy evaluation paradigm learn from each other? Research in International Business and Finance, 47, 18-30.

Duraj, J. (2011). Kształtowanie wartości przedsiębiorstwa społecznego. Zeszyty Naukowe Uniwersytetu Szczecińskiego. Finanse, Rynki Finansowe, Ubezpieczenia, 47, 39-47. 
EC, \& OECD. (2015). Policy brief on social impact measurement for social enterprises: policies for social entrepreneurship. Downloaded from the European Commision, Organisation for Economic Co-operation and Development website: http://bookshop.europa. eu/uri?target=EUB:NOTICE:KE0415192:EN:HTML (access: 12.11.2019).

Głowacki, J. (2010). Mierzenie społecznej wartości dodanej. Ekonomia Społeczna, 1, 26-34.

Głowacki, J. (2013). ESometr już działa! Ekonomia Społeczna, 3, 155-156.

Głowacki, J. (2015). Wartość w ekonomii społecznej. Ekonomia Społeczna, 2, 60-68. https://doi.org/10.15678/ES.2015.2.04

Głowacki, J., \& Jelonek, M. (2013). Mierzenie społecznej wartości dodanej podmiotów ekonomii spotecznej. https://www.isp.org.pl/pl/publikacje/mierzenie-spolecznej-wartoscidodanej-podmiotow-ekonomii-spolecznej (access: 12.11.2019).

Głowacki, J., Płonka, M., \& Rosiek, K. (2012). Wybrane metody oceny społeczno-ekonomicznych efektów działania podmiotów ekonomii społecznej. In M. Frączek, J. Hausner, \& S. Mazur (ed.), Wokót ekonomii społecznej. Uniwersytet Ekonomiczny. Małopolska Szkoła Administracji Publicznej.

Goleński, W. (2017). Efektywność organizacyjna podmiotów ekonomii społecznej — próba operacjonalizacji. Ekonomia Spoteczna, 1, 7-21.

Guz, H. (2008). Monitoring i ewaluacja jako narzędzia wspierające zarządzanie przedsięwzięciami o społecznym charakterze. Ekonomia Społeczna, 2, 43-52.

Harlock, J. (2013). Impact measurement practice in the UK third sector: a review of emerging evidence. http://epapers.bham.ac.uk/1800/ (access: 12.11.2019).

Herbst, K. (2006). Czy ekonomia społeczna wspomoże rozwój lokalny? Fundacja Inicjatyw Społeczno-Ekonomicznych.

Jastrzębska, E. (2017). Wpływ przedsiębiorstw na otoczenie - ujęcie w raportach niefinansowych. Marketing i Rynek, 11 (CD), 158-173.

Juraszek-Kopacz, B., \& Tyrowicz, J. (2008). Zmierzyć, co niemierzalne, czyli o pomiarze oddziaływania społecznego. https:/fakty.ngo.pl/files/civicpedia.pl/public/raporty/ pomiar_oddzialywania.pdf (access: 12.11.2019).

Kafel, T. (2012). Metoda Prove and Improve jako narzędzie pomiaru społecznego oddziaływania organizacji pozarządowych. Acta Universitatis Lodziensis, Folia Oeconomica, 265, 125-139.

Krawczyk, K., \& Kwiecińska, D. (2008). Audyt społeczny jako metoda oceny działalności przedsiębiorstw społecznych na tle innych sposobów określania społecznej wartości dodanej. In M. Adamczyk, \& J. Hausner (eds), Wspieranie ekonomii społecznej. Uniwersytet Ekonomiczny. Małopolska Szkoła Administracji Publicznej.

Łącka, I. (2015). Problemy oceny efektywności podmiotów ekonomii społecznej. Prace Naukowe Uniwersytetu Ekonomicznego we Wroctawiu, 1(395 "Finanse i rachunkowość na rzecz zrównoważonego rozwoju — odpowiedzialność, etyka, stabilność finansowa”), 241-251.

Maas, K., \& Liket, K. (2011). Talk the Walk: Measuring the Impact of Strategic Philanthropy. Journal of Business Ethics, 100(3), 445-464. Downloaded from JSTOR. 
Moher, D. (2009). Preferred Reporting Items for Systematic Reviews and Meta-Analyses: The PRISMA Statement. Annals of Internal Medicine, 151(4), 264.

Moroń, D., \& Klimowicz, M. (2016). Zastosowanie stopy społecznego zwrotu z inwestycji (SROI) jako wskaźnika mierzenia efektywności projektów społecznych. Wroctawskie Studia Politologiczne, 21, 67-81.

Oramus, M. (2011). Przydatność metody Social Return on Investment dla małych podmiotów ekonomii społecznej : studium przypadku fundacji Ale heca! Ekonomia Spoteczna, 2, 61-74.

Orłowska, A., Mazur, Z., \& Łaguna, M. (2017). Systematyczny przegląd literatury: Na czym polega i czym różni się od innych przeglądów? Ogrody Nauk i Sztuk, 7.

Płonka, M. (2008). Wybrane problemy rachunku kosztów i korzyści społecznych podmiotów ekonomii społecznej. Ekonomia Społeczna, 2, 26-34.

Płonka, M. (2013). Społeczna wartość dodana towarzystw ubezpieczeń wzajemnych w Polsce - aspekty teoretyczne i praktyczne. Ekonomia Społeczna, 2, 20-31.

Rościszewska, E. (2015). Ocena efektywności realizacji ustug. FISE Fundacja Inicjatyw Społeczno-Ekonomicznych.

Rymsza, M. (2011). Więziotwórcze funkcje przedsiębiorstw społecznych. Polityka Spoteczna, 38(7 (448)), 14-18.

SIIT. (2014). Measuring Impact: Subject Paper of the Impact Measurement Working Group. https://www.thinknpc.org/resource-hub/impact-measurement-working-group-measuri ng-impact/ (access: 12.11.2019).

Smoter, M. (2012). Metoda audytu społecznego na przykładzie Stowarzyszenia SIEMACHA. Ekonomia Spoteczna, 1, 54-68.

Somers, A. B. (2005). Shaping the Balanced Scorecard for use in UK social enterprise. Social Enterprise Journal, 1, 43-56.

Szarfenberg, R. (2010). Zagadnienia terminologiczne. In B. Szatur-Jaworska (ed.), Ewaluacja w stużbach społecznych: praca zbiorowa. (24-33). Mazowieckie Centrum Polityki Społecznej.

Szatur-Jaworska, B. (2010). Typologie ewaluacji. In B. Szatur-Jaworska (ed.), Ewaluacja w stużbach społecznych: praca zbiorowa. (34-44). Mazowieckie Centrum Polityki Społecznej.

Świeczkowski, P. (2011). Oddziaływanie wybranych spółdzielni socjalnych na gospodarkę lokalną miasta Krakowa, na przykładzie metody Local Multiplier 3 (LM3). Biuletyn Ekonomia Spoteczna w Matopolsce, 4, 31-35.

Worek, B. (2008). Ewaluacja a rozwój ekonomii społecznej. Ekonomia Społeczna, 2, 93-94.

Wronka, M. (2014). Sukces i jego pomiar w przedsiębiorstwach społecznych — próba operacjonalizacji. Prace Naukowe Watbrzyskiej Wyższej Szkoty Zarzązania i Przedsiębiorczości, 27(2) Zarządzanie strategiczne: rozwój koncepcji i metod, 363-387.

Wróblewska, M. N. (2017). Ewaluacja „wpływu społecznego”? Nauka i Szkolnictwo Wyższe, 1(49). 


\begin{tabular}{|c|c|c|c|c|}
\hline 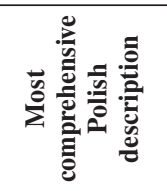 & 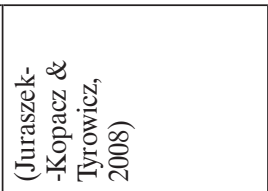 & 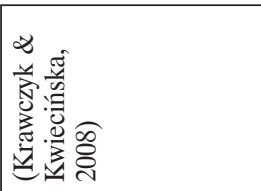 & 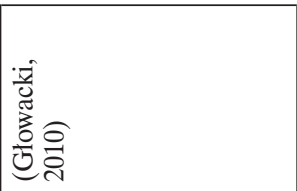 & 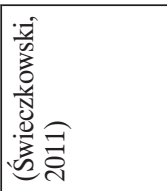 \\
\hline 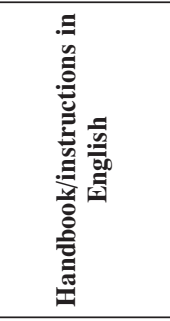 & 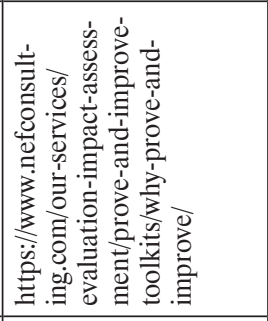 & 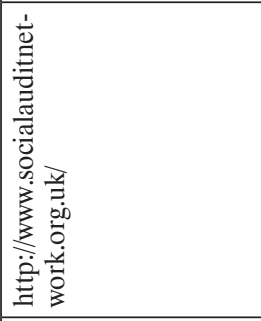 & 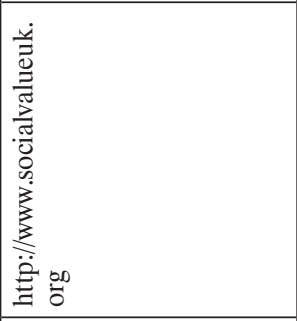 & 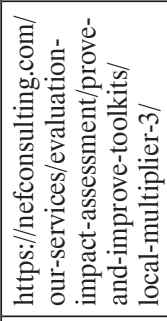 \\
\hline 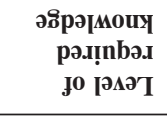 & 苞 & 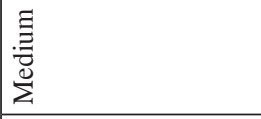 & $\begin{array}{l}.50 \\
.000 \\
\end{array}$ & 意 \\
\hline 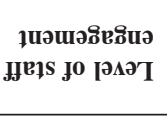 & 㿣 & $\begin{array}{l}.50 \\
.00 \\
1\end{array}$ & 禀 & 声 \\
\hline 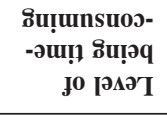 & 竘 & .00 & 竭 & 罭 \\
\hline & 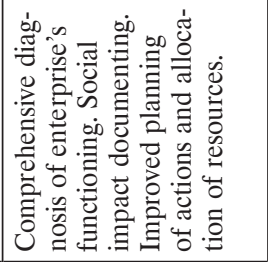 & 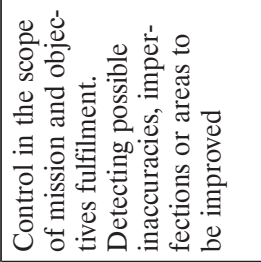 & 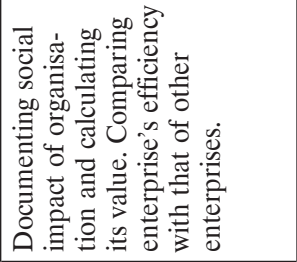 & 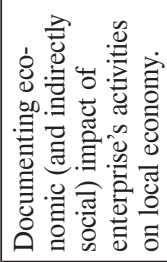 \\
\hline 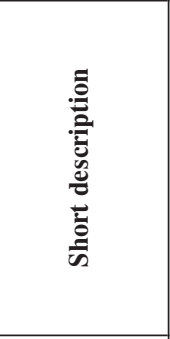 & 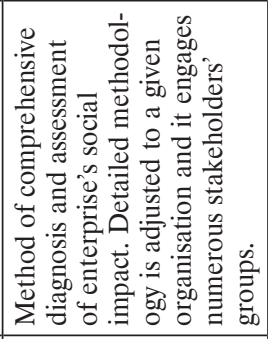 & 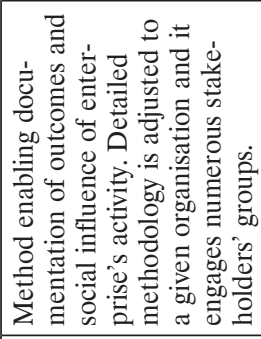 & 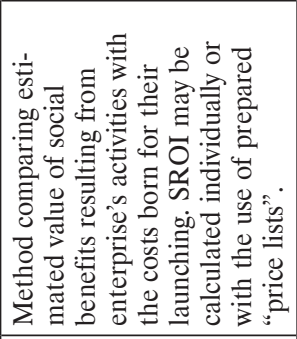 & 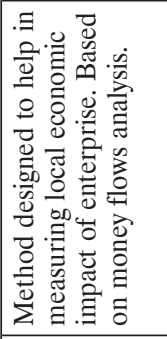 \\
\hline ио!̣ழ!ıә.IqqV & $\begin{array}{l}\vec{z} \\
\stackrel{z}{a} \\
\text { D }\end{array}$ & $\sum_{\pi}$ & $\begin{array}{l}0 \\
0 \\
\approx \\
\approx\end{array}$ & $\sum_{-1}^{\infty}$ \\
\hline 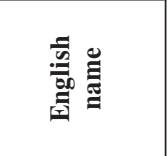 & 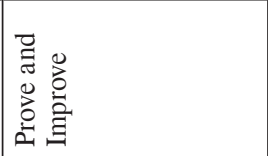 & 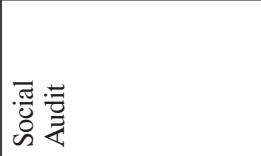 & 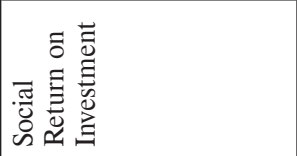 & 离 \\
\hline 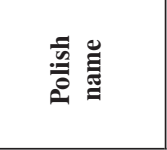 & 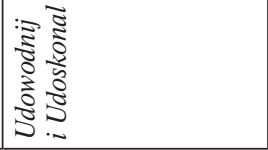 & 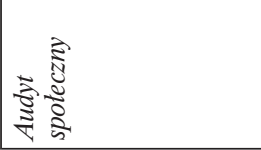 & 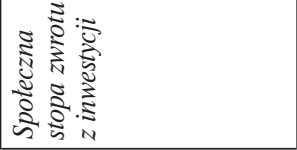 & 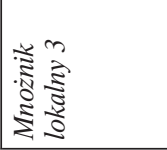 \\
\hline
\end{tabular}




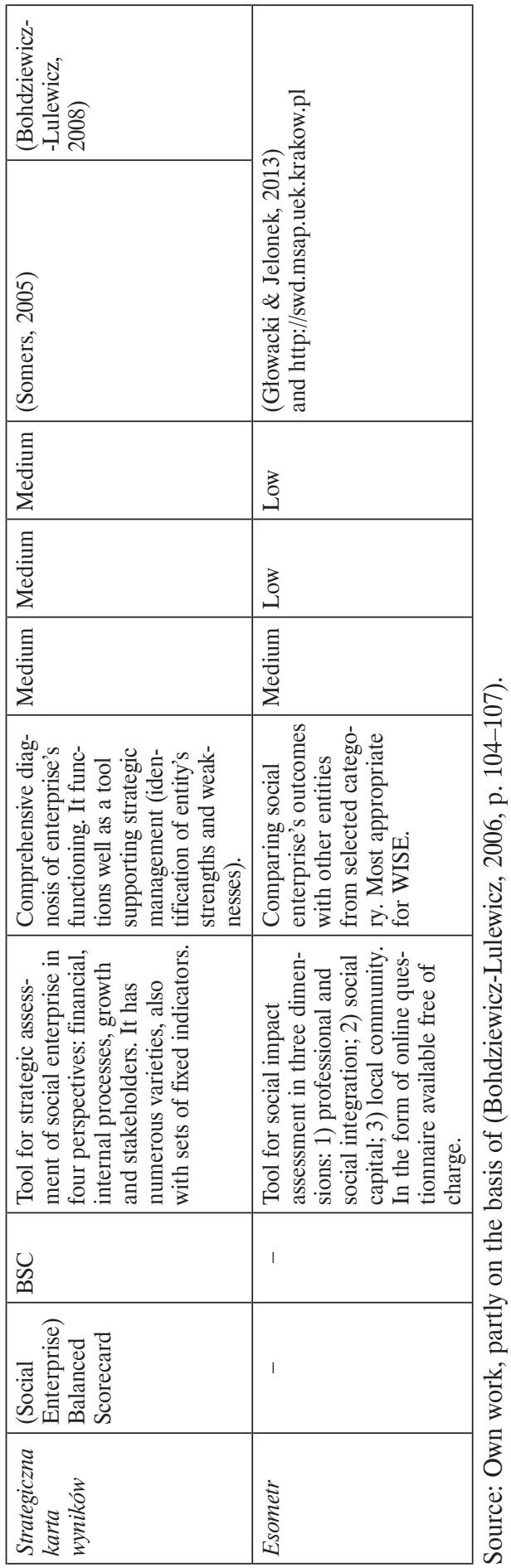

